\title{
SEKOLAH ALAM: ALTERNATIF PENDIDIKAN RAMAH ANAK
}

\author{
Ahmad Hamdani \\ Universitas Islam Negeri (UIN) Syarif Hidayatullah Jakarta \\ E-mail: nidhani94@gmail.com
}

\begin{abstract}
Abstrak: Sekolah sudah sejak lama dipercaya oleh banyak kalangan sebagai tempat untuk memperoleh pendidikan. Kepercayaan ini disertai pemberian tanggung jawab kepada sekolah untuk menghadirkan lingkungan yang aman dan nyaman bagi peserta didik. Namun, data dari riset yang dilakukan LSM Plan International dan International Center for Research on Women (ICRW) yang dirilis awal Maret 2015 menunjukan, 84\% anak di Indonesia mengalami kekerasan di sekolah. Hal ini merupakan paradoks ditengah lahirnya UU Nomor 35 tahun 2014. Padahal anak adalah tunas bangsa, aset berharga yang merupakan bagian dari suatu negara. Banyaknya kasus kekerasan pada anak yang terjadi di sekolah secara langsung telah mencoreng citra pendidikan yang selama ini dipercaya oleh banyak kalangan sebagai tempat dimana proses humanisasi berlangsung. Minimnya sekolah yang hadir dengan membawa konsep lingkungan ramah anak menjadi salah satu penyebabnya. Oleh karena itu, Indonesia perlu memiliki sekolah tidak hanya dengan konsep pendidikan unggul, namun juga dapat menghadirkan lingkungan ramah anak. Penelitian ini merupakan penelitian kualitatif interpretatif, yang dilakukan di Sekolah Alam Bintaro Kota Tangerang Selatan. Data primer diambil dari observasi dan wawancara sedangkan data sekunder diperoleh dari studi kepustakaan. Analisis teks yang digunakan adalah bersifat kualitatif, yaitu merupakan proses penyederhanaan data kedalam bentuk yang mudah dipahami.Hasil penelitian menunjukan bahwa kehadiran Sekolah Alam di Bintaro Kota Tangerang Selatan membawa angin segar ditengah maraknya kasus kekerasan yang terjadi di sekolah. Sekolah Alam Bintaro Kota Tangerang telah menunjukan bagaimana sistem sekolah yang dibentuk secara apik mampu menghadirkan alternatif lingkungan pendidikan yang layak bagi anak.
\end{abstract}

Kata Kunci: Anak, Kedudukan Anak, Kekerasan di Sekolah, dan Sekolah Alam

\section{Pendahuluan}

Anak adalah tunas bangsa, aset berharga yang merupakan bagian dari suatu negara. Anak memiliki peran yang sangat strategis, yaitu sebagai succesor keberhasilan suatu bangsa. Di dalam konteks keindonesiaan, anak merupakan penerus yang dicitakan dapat mewujudkan citacita bangsa. Bahkan peran strategis anak ini telah disadari oleh masyarakat dunia yang kemudian melahirkan pasal 2 undang-undang nomor 4 tahun 1976 tentang kesejahteraan anak dan konvensi hak anak yang telah diratifikasi dengan dikeluarkanya Keputusan Presiden RI No. 28 tahun 1990 dimana menyebutkan, bahwa anak harus mendapatkan perlindungan dan dipenuhi hak-haknya untuk tumbuh dan berkembang secara normal, dan anak-anak diberikan kesempatan berpartisipasi yaitu dengan didengarkan suara hatinya, diberi kesempatan mengembangkan potensinya sesuai dengan keinginan anak. Berdasarkan hal inilah kemudian muncul urgensi perlindungan terhadap anak.

Namun, sampai saat ini perlindungan terhadap anak belum begitu menggembirakan. Kasus kekerasan yang terjadi pada anak di Indonesia masih menjadi hal menakutkan. Komisi Perlindungan Anak Indonesia (KPAI) menyatakan, kekerasan pada anak selalu meningkat setiap tahun. Hasil pemantauan KPAI dari 2011 sampai 2014, terjadi peningkatan yang 
sifnifikan. "Tahun 2011 terjadi 2178 kasus kekerasan, 2012 ada 3512 kasus, 2013 ada 4311 kasus, 2014 ada 5066 kasus," kata Wakil Ketua KPAI, Maria Advianti. Dia memaparkan, 5 kasus tertinggi dengan jumlah kasus per bidang dari 2011 hingga april 2015. Pertama, anak berhadapan dengan hukum hingga april 2015 tercatat 6006 kasus. Selanjutnya, kasus pengasuhan 3160 kasus, pendidikan 1764 kasus, kesehatan dan napza 1366 kasus serta pornografi dan cybercrime 1032 kasus (www.kpai.go.id). Bahkan dalam sebuah riset yang dilakukan LSM Plan International dan International Center for Research on Women (ICRW) yang dirilis awal Maret 2015 ini menunjukkan fakta mencengangkan terkait kekerasan anak di sekolah. Terdapat $84 \%$ anak di Indonesia mengalami kekerasan di sekolah. Angka tersebut lebih tinggi dari tren di kawasan Asia yakni 70\% (www.news.liputan6.com).

Berdasarkan data di atas, tergambar jelas bahwa kekerasan pada anak sudah masuk ke dalam tahap yang mengkhawatirkan. Padahal Indonesia memiliki sejumlah peraturan perundang-undangan yang melindungi anak dari tindak kekerasan. Seperti UU Nomor 35 Tahun 2014 tentang Perlindungan Anak, Instruksi Presiden Nomor 5 Tahun 2014 tentang Gerakan Nasional Anti-kejahatan Seksual terhadap anak, dan UU Nomor 11 Tahun 2012 tentang Sistem Peradilan Pidana Anak. Namun penerapan perangkat hukum ini masih terbentur beragam kendala seperti ketidaktahuan masyarakat dan kurangnya komitmen pemerintah daerah. Penerapan yang belum optimal ini menjadikan lingkungan ramah anak belum bisa terwujud, sehingga menjadikan anak-anak di Indonesia belum sepenuhnya terlindungi.

Sebuah ironi ketika kasus kekerasan pada anak berkembang sampai ke sekolah. Berdasarkan data di atas, kasus kekerasan pada anak di sekolah terjadi sebanyak 1764 kasus. Ini artinya, sekolah sebagai sebuah lembaga pendidikan yang dipercaya oleh banyak kalangan sebagai sebuah lembaga di mana proses humanisasi berlangsung ternyata belum terlaksana secara optimal. Keberadaanya yang dicitakan mampu mendongkrak kompetensi peserta didik sehingga akan mensejahterakan bangsa ternyata belum bisa terealisasi secara utuh. Padahal, Undang-undang Sistem Pendidikan Nasional No. 20 tahun 2003 Bab II Pasal 3, secara jelas menyebutkan bahwa tujuan pendidikan nasional adalah mengembangkan potensi peserta didik agar menjadi manusia yang beriman dan bertakwa kepada Tuhan Yang Maha Esa, berakhlak mulia, sehat, berilmu, cakap, kreatif, mandiri, dan menjadi warga negara yang demokratis dan bertanggung jawab.

Pembangunan pendidikan nasional sampai saat ini belum mencapai hasil sesuai yang diharapkan. Indonesia belum dapat melepaskan diri dari persoalan dekadensi moral. Di dalam konteks schooling misalnya, sekolah dianggap gagal dalam menghasilkan manusia pembelajar. Krisis yang menggejala adalah terpinggirkannya pembentukan karakter, akhlak, moral, dan budi pekerti yang kemudian menderivat menjadi aksi tawuran dan kekerasan pada anak. Maraknya kasus kekerasan yang terjadi pada anak di sekolah, selalu menjadi isu yang menyita perhatian banyak kalangan, hal ini karena dampak yang ditimbulkan tidak hanya mempengaruhi kondisi psikologis, mental dan menghambat perkembangan anak tetapi aktivitasanya tidak hanya dilakukan oleh guru terhadap siswa, tetapi juga oleh siswa terhadap siswa lainnya. Kasus kekerasan pada anak yang terjadi di sekolah tidak saja mencoreng citra pendidikan yang selama ini dipercaya oleh banyak kalangan sebagai sebuah tempat di mana proses humanisasi berlangsung, namun juga menimbulkan sejumlah pertanyaan, bahkan gugatan dari berbagai pihak yang semakin kritis mempertanyakan esensi pendidikan di sekolah dewasa ini. 


\section{8-95 | HARKAT: Media Komunikasi Islam Tentang Gender dan Anak, 11 (1), 2015}

Sekolah sebagai sebuah institusi pendidikan, turut menetukan peradaban di masa mendatang. Sehingga idealnya, sekolah menjadi tempat yang ramah bagi anak didik, dapat memberi jaminan untuk melangsungkan proses pembelajaran. Artinya, sekolah harus memberikan kesenangan, keleluasaan atau kebebasan kepada anak namun tetap terpantau untuk melakukan pengembangan diri secara optimal. Hal ini akan melahirkan rasa suka dan anak akan termotivasi untuk berkreasi sesuai dengan bakat dan minatnya, sehingga pada akhirnya dapat membangun kesadaran kritis sebagai jalan menuju terciptanya kemandirian anak. Sekolah yang ramah juga harus diartikan sebagai suatu kondisi institusi pendidikan yang jauh dari berbagai tindakan kekerasan terhadap anak, baik fisik maupun non fisik. Berangkat dari sinilah, kemudian muncul urgensi pendidikan yang ramah bagi anak.

\section{METODE PENELITIAN}

Penelitian ini adalah penelitian kualitatif interpretatif yaitu penelitian yang datanya dinyatakan dalam keadaan sewajarnya atau sebagaimana adanya, dengan meneraparkan cara kerja yang bersifat sistemik, terarah dan dapat dipertanggungjawabkan, sehingga tidak kehilangan sifat ilmiahnya.

Dalam penelitian ini, data primer diambil dari observasi dan wawancara di Sekolah Alam Bintaro dan data sekunder diperoleh dari studi kepustakaan. Analisis teks yang digunakan adalah bersifat kualitatif, yaitu merupakan proses penyederhanaan data kedalam bentuk yang mudah dipahami dan dibaca.

Adapun tujuan penelitian ini adalah untuk menginformasikan kepada masyarakat Indonesia khususnya pemerintah, tenaga pendidik, mahasiswa dan para pemerhati anak tentang pentingnya sekolah yang membawa konsep ramah anak. Keberadaan Sekolah Alam Bintaro dalam memberikan fasilitas pendididikan ramah anak telah memberikan gambaran bagaimana seharusnya anak diperlakukan dalam sebuah sistem pendidikan.

\section{HASIL DAN PEMBAHASAN}

\section{Pengertian dan Kedudukan Anak}

Anak merupakan generasi penerus bangsa terutama bagi pembangunan nasional, sehingga harus diperhatikan dan dibina sedini mungkin agar menjadi insan yang berkualitas dan berguna bagi bangsa. Keberada anak dicitakan mampu mewujudkan cita-cita suatu negara. Peran sentral ini kemudian memunculkan urgensi pemahaman yang komprehensif terhadap anak.

Pengertian anak secara umum dipahami masyarakat adalah keturunan kedua setelah ayah dan ibu (WJS. Poerdarminta, 1992: 38-39). Sekalipun dari hubungan yang tidak sah dalam kaca mata hukum, ia tetap dinamakan anak. Pada definisi ini terlihat tidak adanya batas usia untuk anak. Oleh karena itu, pasal 1 (1) UU Nomor 23 Tahun 2002 mendefinisikan secara lebih spesifik, bahwa anak adalah seseorang yang belum berusia 18 (delapan belas tahun) termasuk anak yang masih dalam kandungan.

Berdeda dengan Konvensi Hak Anak (KHA), yang mendefinisikan anak sebagai manusia yang berusia dibawah 18 tahun, kecuali berdasarkan undang-undang yang berlaku bagi anak yang ditentukan bahwa usia dewasa telah mencapai lebih awal (lihat KHA, Pasal 1). Dalam pasal ini, terlihat bahwa batas usia kedewasaan dalam aturan hukum sebuah negara mungkin berbeda dengan ketentuan KHA. Pada pasal ini juga tersirat pesan, bahwa negara dituntut untuk meratifikasi KHA dimana peraturan-peraturan hukumnya disesuaikan dengan KHA.

Jika kita melihat dengan kacamata Hukum Perkawinan Indonesia, anak merupakan kelompok yang belum mencapai usia 18 tahun atau belum pernah melangsungkan perkawinan 
dan ada dibawah kekuasaan orang tuanya. Selama mereka tidak dicabut dari kekuasaan (Pasal 47, UU. No. 1 Tahun 1974 tentang Perkawinan). Berbeda dengan Kompilasi Hukum Islam, berdasarkan pasal 98 (1) mendefinisikan, bahwa batas usia anak yang mampu berdiri sendiri atau dewasa adalah usia 21 tahun, sepanjang anak tersebut tidak bercacat fisik maupun mental atau belum pernah melangsungkan perkawinan (Intruksi Presiden, 2001: 50).

Berdasarkan definisi dan pendapat di atas, terlepas dari kacamata apa mendeskripsikan anak, dapat di ambil kesimpulan bahwa anak adalah kelompok manusia dengan usia di bawah 18 tahun, belum melangsungkan perkawinan dan tidak mengalami cacat mental. Lebih lanjut Hastuti dalam bukunya Psikologi Perkembangan Anak menjelaskan, bahwa anak merupakan makhluk yang membutuhkan perhatian, kasih sayang dan tempat bagi perkembangannya. Selain itu, anak merupakan pribadi yang masih bersih dan peka terhadap rangsangan-rangsangan yang berasal dari lingkungan. Anak juga merupakan bagian dari keluarga, dan keluarga memberikan kesempatan bagi anak untuk belajar tingkah laku yang penting untuk perkembangan yang cukup baik dalam kehidupan bersama (Hastuti, 2012: 7). Berdasarkan hal tersebut, maka menjadi penting untuk senantiasa menjaga tumbuh kembang anak dengan menyediakan lingkungan yang ramah anak. Urgensi menyediakan lingkungan ramah anak selain karena peran sentral yang sedang diemban seorang anak namun juga tuntutan kedudukan anak.

Membahas kedudukan anak, maka akan berhubungan dengan status yang disandangnya. Kedudukan dapat diartikan sebagai keadaan dimana seseorang itu hidup menunjukan kepada suatu hubungan kekeluargaan tertentu (Vollmar,1996: 60). Dalam KHA, anak-anak dikategorikan sebagai kelompok yang rentan (vulnerable groups), sama halnya seperti: pengungsi (refugees), pengungsi dalam negeri (internally displaced persons/IDP's), kelompok minoritas (national minorities), perempuan (women), maupun pekerja migran (migrant workers). Pengkategorian serupa juga dilakukan oleh Komite PBB untuk Hak-Hak Ekonomi, Sosial, dan Budaya. KHA menyatakan bahwa negara menjamin bahwa tidak ada anak yang akan dikenakan penyiksaan atau kekejaman lainnya, ketidakmanusiawian atau penghinaan atau hukuman. Tidak ada anak yang akan dihilangkan kebebasannya secara tidak sah atau sewenang-wenang.

Hal tersebut kemudian ternarasikan dalam Undang-undang No. 23 Tahun 2002 tentang Perlindungan Anak, dimana menjelaskan bahwa setiap anak berhak untuk dapat hidup, tumbuh, berkembang, dan berpartisipasi secara wajar sesuai dengan harkat dan martabat kemanusiaan, serta mendapat perlindungan dari kekerasan dan diskriminasi. Setiap anak selama dalam pengasuhan orang tua, wali, atau pihak lain manapun yang bertanggung jawab atas pengasuhan (termasuk lembaga pendidikan), berhak mendapat perlindungan dari perlakuan: diskriminasi, eksploitasi, baik ekonomi maupun seksual, penelantaran, kekejaman, kekerasan, penganiayaan, ketidakadilan dan perlakuan salah lainnya.

Undang-undang No. 23 Tahun 2002 secara narasi memang terlihat begitu menjunjung tinggi perlindungan anak yang secara jelas memgamanatkan untuk menyediakan lingkungan ramah bagi anak. Namun, jika kita lihat secara praktis masih banyak yang harus dibenahai. Lingkungan yang tidak ramah yang kemudian menderivat menjadi kekerasan pada anak yang sampai saat ini masih menjadi momok menakutkan. 


\section{Kekerasan Pada Anak dan Sekolah Alam sebagai Solusi}

Sekolah sudah sejak lama dipercaya oleh banyak kalangan sebagai tempat pendidikan. Pendidikan merupakan sebuah proses dengan metode-metode tertentu shingga orang memperoleh pengetahuan, pemahaman, dan cara bertingkah laku yang sesuai dengan kebutuhan (Muhibbin Syah, 2013: 10). Pendidikan merupakan sebuah bimbingan jasmani dan rohani untuk membentuk kepribadian utama, membimbing keterampilan jasmaniah dan rohaniyah sebagai perilaku konkret yang memberi manfaat pada kehidupan masyarakat (Ahmad Marimba, 1980: 45). Hal inilah yang kemudian menjadikan sekolah sangat diperlukan kehadirannya. Lingkungan sekolah juga merupakan tempat dimana anak melakukan proses humanisasi dan sarana mengembangkan potensi yang ada pada dirinya. Di sini anak akan menemukan banyak orang baru, seperti guru dan teman-temannya. Sebuah lingkungan yang dirancang dalam rangka mempersiapkan generasi emas, generasi penerus bangsa.

Namun, miminya sekolah yang hadir dengan membawa konsep lingkungan ramah anak, dan orientasi sekolah yang hanya berfokus pada ranah kognitif memicu terjadinya banyak kasus kekerasan di sekolah, yang kini menjadi momok tersendiri bagi masyarakat. Riset yang dilakukan LSM Plan International dan International Center for Research on Women (ICRW) yang dirilis awal Maret 2015 menunjukkan fakta mencengangkan terkait kekerasan anak di sekolah. Terdapat $84 \%$ anak di Indonesia mengalami kekerasan di sekolah. Angka tersebut lebih tinggi dari tren di kawasan Asia yakni 70\%. Kasus kekerasan pada anak yang terjadi di sekolah telah mencoreng citra pendidikan dan memudarkan kharismanya yang selama ini dipercaya oleh banyak kalangan sebagai sebuah tempat di mana proses humanisasi berlangsung. Undang-undang Sistem
Pendidikan Nasional No. 20 tahun 2003 pun belum mampu memberikan pengaruh yang signifikan untuk sistem pendidikan di negeri ini.

Banyak orang menganggap kekerasan pada anak hanya dalam konteks yang sempit, terbatas hanya pada penganiayaan atau pembunuhan, padahal kekerasan bentuknya bermacam-macam. Jika orang sepakat bahwa setiap tindakan yang mengganggu fisik atau kondisi psikologis anak adalah suatu bentuk kekerasan, maka seharusnya orang menyadari bahwa rasisme atau bulliying dapat juga dianggap sebagai bentuk kekerasan. Menurut Jamil Salmi (2005:31-32), ada empat jenis kekerasan yang pokok, yaitu: 1) Kekerasan langsung (direct violence), 2) Kekerasan tidak langsung (indirect violence), 3) Kekerasan represif (repressive violence), dan 4) Kekerasan alienatif (alienating violence).

Pasal 13 UU Perlindungan Anak menyebutkan prilaku yang termasuk ke dalam kekerasan pada anak secara lebih spesifik: diskriminasi; eksploitasi, baik ekonomi maupun seksual; penelantaran; kekejaman, kekerasan, dan penganiayaan; ketidakadilan; dan perlakuan salah lainnya. Masalahnya terkadang banyak pihak yang belum memahami hal tersebut, sehingga menganggap apa yang dilakukannya adalah masih dalam tataran wajar.

Rentetan kasus kekerasan pada anak di sekolah, seperti pengeroyokan terhadap siswi SD di Padang yang terjadi di jam belajar, kekerasan yang terjadi di SDN 07 Pagi, Jakarta Selatan, penyekapan dan penganiayaan terhadap siswi SMA di Yogyakarta hanya karena tato Hello Kitty, dan kasus yang terjadi di Jakarta International School, nampaknya sudah menunjukkan, bahwa banyak masalah dengan pendidikan di negeri ini. Kasus kekerasan pada anak, harus segera disudahi. Jika tidak hal ini akan menjadi bom waktu bagi Indonesia. Anakanak yang sejatinya merupakan tunas bangsa yang kelak akan melanjutkan perjuangan malah terenggut haknya. Selain itu kekerasan pada anak 
dapat berdampak jangka pendek ataupun jangka panjang.

1. Jangka pendek. Dampak jangka pendek terutama berhubungan dengan masalah fisik antara lain: lembam, lecet, luka bakar, patah tulang, kerusakan organ, robekan selaput dara, keracunan, gangguan susunan saraf pusat. Di samping itu seringkali terjadi gangguan emosi atau perubahan perilaku seperti pendiam, menangis, dan menyendiri.

2. Jangka panjang. Dampak jangka panjang dapat terjadi pada kekerasan fisik, seksual, maupun emosional.

a) Kekerasan fisik. Kecacatan yang dapat mengganggu fungsi tubuh anggota tubuh

b) Kekerasan seksual. Kehamilan yang tidak diinginkan, infeksi menular seksual termasuk HIV/AIDS, gangguan /kerusakan organ reproduksi.

c) Kekerasan emosional. Tidak percaya diri, hiperaktif, sukar bergaul, rasa malu dan bersalah, cemas, depresi, psikosomatik, gangguan pengendalian diri, suka mengompol, kepribadian ganda, gangguan tidur, psikosis, dan penggunaan napza. (http://www.sorasirulo.com).

Berangkat dari kondisi inilah, diperlukan sebuah solusi nyata dalam rangka menciptakan pendidikan ramah anak. Harapan tersebut kemudian muncul dari Sekolah Alam.

Sekolah Alam merupakan sebuah konsep pendidikan yang awalnya digagas oleh Lendo Novo berdasarkan keprihatinannya akan biaya pendidikan yang semakin tidak terjangkau oleh masyarakat. Sebagaimana kita ketahui, paradigma umum dalam dunia pendidikan adalah sekolah berkualitas pasti selalu mahal. Penyebab yang menjadikan sekolah tersebut mahal adalah kebanyakan karena infrastrukturnya. Sebenarnya, kontribusi infrastruktur terhadap kualitas pendidikan tidak lebih dari 30\% dan sisanya kontribusi kualitas pendidikan berasal dari kualitas guru, metode belajar yang tepat, dan buku sebagai gerbang ilmu pengetahuan. Berangkat dari ketiga variabel yang menjadi kualitas pendidikan ini, kemudian Lendo mencoba mengembangkan konsep-konsep Sekolah Alam.

$\begin{array}{cccc}\text { Kehadiran Sekolah Alam mampu } & \text { membawa angin segar ditengah kondisi }\end{array}$ pendidikan di Indonesia sebagaimana tersebut di atas. Keberadaannya ternyata menuai tanggapan yang cukup baik. Walaupun Sekolah Alam biasanya merupakan sekolah inklusi, artinya sekolah yang menyediakan tempat bagi siswa berkebutuhan khusus. Hingga kini, Sekolah Alam sudah mampu tersebar dibanyak kota yang ada di Indonesia. Berprinsip pendidikan bagi semua, sekolah alam percaya bahwa dengan menyatukan antara siswa biasa dan siswa berkebutuhan khusus, masing-masing pihak akan dapat saling belajar. Siswa berkebutuhan khusus akan mendapatkan spektrum normal, sementara siswa biasa akan lebih tumbuh rasa empatinya terhadap sesama.

Selain itu, proses belajar mengajar di Sekolah Alam tidak dikungkung di dalam kelas, melainkan berubah menjadi aktivitas kehidupan nyata yang dihayati dengan kegembiraan karena konsepnya diarahkan agar siswa merasa nyaman. Hal itu sangat membantu anak-anak menikmati masa-masa awal pertumbuhan, dan membangun gambaran positif tentang kehidupan dan bumi yang dihuni, apalagi usia anak-anak yang pengetahuannya ada pada taraf operasional konkrit. Selain itu, gabungan antara pelajaran kelas, latihan outbound, penelitian lapangan (outing), market day, dan lainnya, telah memberikan pemahaman dan kesadaran yang relatif lebih utuh tentang kehidupan, membentuk struktur emosi dan mentalitas yang lebih stabil, serta membangun sikap-sikap keseharian yang lebih baik dari waktu ke waktu. Konsep yang disajikan secara matang ini 


\section{2-95 | HARKAT: Media Komunikasi Islam Tentang Gender dan Anak, 11 (1), 2015}

menjadikan Sekolah Alam layak dijadikan sebuah tawaran solusi untuk sekolah ramah anak.

Program anti Bullying seperti Network People dan Nursing yang diterapkan hampir disemua Sekolah Alam, misalnya, merupakan bentuk riil dalam konsep sekolah ramah anak. Program network people (jaringan orang) biasanya difokuskan pada siswa yang masih kecil. Siswa diminta menuliskan network people mereka siapa saja. Network people ini bisa orangorang terdekat si anak, misalnya kerabat atau guru, kepada siapa anak merasa nyaman bercerita jika terjadi sesuatu kepada mereka. Jadi jaringan orang-orang dekat ini tidak harus dari lingkungan sekolah atau orang tua. Melalui program ini, pendidik akan mengetahui lebih dalam dari kondisi sosial dan emosional anak. Sedangkan program nursing atau buddy system adalah pendampingan. Di Sekolah Alam, siswa benar-benar mendapatkan perhatian intensif dari tenaga pendidiknya. Jika pada sekolah biasa, satu kelas siswa hanya ditangani oleh satu atau dua tenaga pendidik, beda halnya dengan di Sekolah Alam yang bisa mencapai 7 tenaga pendidik. Sistem inilah yang menjadikan perkembangan anak bisa terpantau, sehingga meminimalisir terjadinya kekerasan pada anak.

\section{Mengintip Sekolah Alam Bintaro: Sebuah Hasil Studi Lapangan}

Sekolah Alam Bintaro merupakan salah satu sekolah alam yang ada di Provinsi Banten. Sekolah Alam Bintaro beralamat di Jl. Pondok Pucung Raya No.88, Sektor IX Pondok Aren, Kota Tangerang Selatan, Banten. Banyaknya kasus kekerasan pada anak di Indonesia menjadikan kehadiran sekolah Alam Bintaro cukup mendapatkan respon baik dari masyarakat. Selain membawa konsep Sekolah Alam pada umumnya, Sekolah Alam Bintaro juga memberikan kosep pendidikan yang berdasarkan pada al-Qur'an dan hadist. Konsep dasar yang dipegang yakni, bahwa tujuan manusia diciptakan salah satunya adalah untuk menjadi khalifah di muka bumi. Perpaduan dua konsep tersebut semakin lengkap dengan digunakannya kurikulum yang mengacu pada standar Kemdikbud dan dijadikannya alam sebagai media belajar dalam rangka pembentukan logika berfikir dan karakter anak.

Selain itu, sebagai upaya memfasilitasi terciptanya lingkungan ramah anak, Sekolah Alam Bintaro memprioritaskan 4 pokok materi dalam konsep pendidikan yang dikembangkan:

1. Ahlakul Karimah: menjadikan anak memiliki akhlak yang baik dengan metode utamanya pembiasaan dan keteladanan yang bedasrkan al-Qur'an dan Hadist.

2. Falsafah Ilmu Pengetahuan: menjadikan anak memiliki logika berfikir yang baik, mencermati alam lingkungannya menjadi media belajarnya dengan metode action learning dan diskusi.

3. Kepemimpinan/Leadership: menjadikan anak memiliki sifat kepemimpinan yang kuat.

4. Enterpreneurship: menjadikan anak memiliki kemampuan untuk hidup mandiri dan terbiasa untuk mendapatkan sesuatu dengan kerja keras.

Adapun beberapa kegiatan sebagai implementasi pendidikan ramah di Sekolah Alam Bintaro antara lain tercermin dari pendekatan siswa dengan cerita, belajar sambil bermain, pemajangan hasil karya siswa, tidak ada tindakan fisik sebagai hukuman, kegiatan pembiasaan (tahfidz, iqro, doa-doa, dan salat duha), serta keteladanan guru.

Tentang keteladanan guru, merupakan bagian penting dalam menginternalisasikan nilainilai kehidupan yang luhur kepada siswa. Kepeduliannya akan menjadikan pembelajaran lebih bermakna. Selain itu guru juga memiliki tanggung jawab dalam menciptakan situsi dan lingkungan ramah anak. Sekolah Alam Bintaro 
nampaknya sudah memahami hal tersebut sedari awal, hal ini terdeskripsikan dari mulai recruitment tenaga pendidik, sampai dengan pembinaan rutin bagi tenaga pendidik. Sehingga wajar, apabila sekolah alam mampu mengahadirkan suasana baru dalam dunia pendidikan di Indonesia, terutama dalam menciptakan sekolah ramah anak.

Menariknya dalam pembelajaran, Sekolah Alam Bintaro juga menekankan sikap toleransi, dimana siswa diarahkan untuk bersahabat dengan siapa saja tanpa pilih-pilih, guru selalu mempersilahka siswa yang akan bertanya, guru menerangkan keberagaman yang ada di Indonesia sebagai bentuk cinta terhadap tanah air, hingga guru memanjang hasil karya siswa sebagai bentuk menghargai prestasi siswa.

Berdasarkan temuan di lapangan tersebut, secara langsung sebenarnya Sekolah Alam Bintaro juga telah memperkuat pelaksanaan pendidikan karakter yang telah teridentifikasi dari 18 nilai yang bersumber dari agama, pancasila, budaya, dan tujuan pendidikan nasional yang bersumber dari Puskurbuk (2009: 9-10), yaitu: (1) Religius; (2) Jujur; (3) Toleransi; (4) Disiplin; (5) Kerja keras; (6) Kreatif; (7) Mandiri; (8) Demokratis; (9) Rasa Ingin Tahu; (10) Semangat Kebangsaan; (11) Cinta Tanah Air; (12) Menghargai Prestasi; (13) Bersahabat/Komunikatif ; (14) Cinta Damai; (15) Gemar Membaca; (16) Peduli Lingkungan; (17) Peduli Sosial; (18) Tanggung Jawab. Artinya, cerminan lingkungan sekolah yang ramah anak telah tampak pada Sekolah Alam Bintaro, dimana secara sadar sekolah ramah anak telah direncanakan dalam sistem penyelenggaraan sekolah yang ada.

\section{Menggagas Pendidikan Ramah Anak}

Di dalam konteks keindonesiaan, anak memiliki peran yang sangat strategis, yaitu sebagai succesor keberhasilan suatu bangsa yang dicitakan dapat mewujudkan cita-cita suatu negara. Disiniah urgensi pendidikan ramah anak untuk direalisasikan di Indonesia. Ada beberapa hal yang harus diperhatikan dalam mengagas pendidikan yang ramah bagi anak, yaitu:

a. Sekolah dituntut untuk mampu menghadirkan dirinya sebagai sebuah media, tidak sekadar tempat yang menyenangkan bagi anak untuk belajar.

b. Sekolah perlu menciptakan ruang bagi anak untuk berbicara mengenai nilai-nilai positif. Tujuannya agar terjadi dialektika antara nilai yang diberikan oleh pendidikan kepada anak.

c. Tidak mengabaikan konsep "dunia anak adalah bermain”. Artinya, sekolah mampu menjadi tempat bermain yang memperkenalkan persaingan yang sehat dalam sebuah proses belajar-mengajar. $\mathrm{Hal}$ ini karena pada usia anak, melalui bermaianlah ada paket lengkap, yaitu proses belajar dan bekerja.

d. Siswa dilibatkan dalam berbagai aktifitas yang mengembangkan kompetensi dengan menekankan proses belajar melalui berbuat sesuatu (learning by doing, demo, praktek, dll).

e. Kreasi Penataan Kelas. Untuk merealisasikan hal ini, siswa harus dilibatkan dalam penataan bangku, dekorasi dan ilustrasi yang menggambarkan ilmu pengetahuan, dll. Bisa juga dilakukan inovasi penataan bangku belajar. Hal tersebut karena, lazimnya penataan bangku secara klasikal (berbaris ke belakang) mungkin akan membatasi kreatifitas murid.

f. Sekolah harus memiliki fasilitas air bersih dan sanitasi, serta fasilitas kesehatan. Fasilitas sanitasi seperti toilet dan tempat cuci tersebut, disesuaikan dengan postur dan usia anak. Di sekolah juga diterapkan kebijakan atau peraturan yang mendukung kebersihan dan kesehatan. Kebijakan atau peraturan ini, 


\section{4-95 | HARKAT: Media Komunikasi Islam Tentang Gender dan Anak, 11 (1), 2015}

disepakati, dikontrol, dan dilaksanakan oleh semua murid (dari-oleh-dan untuk murid).

g. Sekolah Alam harus mampu memunculkan kesan sekolah berbasis komunitas. Maksudnya, mampu mendorong kemitraan setempat dalam pengembangan pendidikan ramah anak.

Kehadiran Sekolah Alam adalah wujud kepedulian dalam rangka mewujudkan pendidikan ramah anak. Oleh karena itu, keberadaannya harus dimanfaatkan dengan baik. Pemerintah sebagai pemegang otoritas juga diharapkan memberikan perhatian dan menjalin hubungan harmonis dengan Sekolah Alam. Sehingga, perannya sebagai lembaga pendidikan bisa lebih teroptimalkan.

\section{PENUTUP}

Sekolah yang ramah diartikan sebagai suatu kondisi institusi pendidikan yang jauh dari berbagai tindakan kekerasan terhadap anak, baik fisik maupun non fisik. Sekolah seperti ini idealnya akan menjadi tempat yang ramah bagi anak didik, memberikan kesenangan, keleluasaan atau kebebasan kepada anak, namun tetap terawasi untuk melakukan pengembangan diri secara optimal. Hal ini secara langsung akan melahirkan rasa suka dan anak akan termotivasi untuk berkreasi sesuai dengan bakat dan minatnya, sehingga akhirnya dapat membangun kesadaran kritis sebagai jalan menuju terciptanya kemandirian anak.

Keberadaan Sekolah Alam di Indonesia membawa angin segar ditengah banyaknya kasus kekerasan yang terjadi di Sekolah. Sekolah Alam Bintaro sebagai tempat penelitian penulis, telah menunjukan bagaimana sistem sekolah yang dibentuk secara apik mampu menghadirkan lingkungan yang ramah bagi anak.

\section{DAFTAR PUSTAKA}

Hastuti. 2012. Psikologi Perkembangan Anak. Yogyakarta: Tugu Plubisher.

Intruksi Presiden No. 1 tahun 1991. 2001. Kompilasi Hukum Islam di Indonesia, Jakarta: Direktorat Pembinaan Badan peradilan Agma Islam, Direktorat Jendral Pembinaan Kelembagaan Agama Islam, Departemen Agama Islam.

Konvensi hak Anak. 2000. Jakarta: Departemen Kehakiman dan HAM.

Marimba, Ahmad. 1980. Pengantar Filsafat Pendidikan Islam. Semarang: Ramadhani.

Puskurbuk. 2011. Pedoman Pelaksanaan Pendidikan Karakter. Depdiknas.

Salmi, Jamil. 2005. Violence and Democratic Society: Hooliganisme dan Masyarakat Demograsi. Yogyakarta: Pilar Media.

Syah, Muhibbin. 2013. Psikologi Pendidikan. Cet XVII. Bandung: PT Remaja Rosdakarya.

Undang-undang No. 20 Tahun 2003 tentang Sistem Pendidikan Nasional

Undang-undang No. 23 Tahun 2002 tentang Perlindungan Anak

Undang-undang No. 1 Tahun 1974 tentang Perkawinan

Vollmar, HFA. 1996 Pengantar Studi Hukum Perdata, terj. IS. Adiwinarta, jil, Cet. IV. Jakarta: Raja Grafindo.

WJS. Poerdarminta. 1992. Kamus Umum Bahasa Indonesi. Jakarta: Balai Pustaka.

Undang-undang No. 23 Tahun 2004 tentang Penghapusan Kekerasan Dalam Rumah Tangga

Wirawan, Sarlito, Laki-laki Memang Terlambat

Dewasa, Harian Seputar Indonesia (Sindo), Kamis 13 Desember 2007. 
Zahrah, Muhammad Abû, Al-Ahwwâl alSyakhshiyyah, (Kairo: Dâr al-Fikr al'Arabî, t.th.).

Zamakhsyarî, Abû al-Qâsim Jâr Allah Mahmûd ibn Umar, Al-Kasysyâf 'an Haqâ'iq alTanzîl wa 'Uyûn al-Aqâwîl fî̀ Wujûh alTa’wîl, Jilid I (Beirut: Dâr al-Fikr, t.th).

Zuhaylî, Wahbbah, Tafsîr al-Munîr fî̀ al-Aqîdat wa al-Syarî‘at wa al-Manhâj, (Beirût: Dâr al-Fikr al-Mu'ashir, t.th.).
Internet

http://www.kpai.go.id/berita/kpai-pelakukekerasan-terhadap-anak-tiap-tahunmeningkat/

http://news.liputan6.com/read/2191106/surveiicrw-84-anak-indonesia-alami-kekerasandi-sekolah

http://www.sorasirulo.com/2014/06/28/kekerasan-padaanak-dan-dampaknyal 